\title{
APPLICATION OF SQ3R LEARNING MODEL FOR IMPROVING STUDENT LEARNING OUTCOMES AND ACTIVITIES IN LEARNING BAHASA INDONESIA
}

\author{
YUSMI
}

Volume 1 Nomor 2

JIPS

ISSN: 2579-5449

E-ISSN: 2597-6540

\begin{abstract}
To learn a lesson well, we need to hear, see, ask questions about it, and discuss it with others. Not only that, teachers need to "do it", that is to describe something in their own way, to show their example, to try to practice their skills and to do tasks that demand the knowledge they have gained. Problems to be studied in this research are: Does using SQ3R model can improve student learning result of SD N 30 Timbulun in Indonesian language lesson? Steps taken in using the SQ3R learning model? The location of this research is SD Negeri 30 Timbulun. Subjects and Characteristics of students. Improved subjects are Indonesian subjects, while the number of students who became the target of research in class I as many as 27 people consisting of 15 women and 12 men. This research is in the form of process (observation and field note) and result of test. Observation is used to get data about students in following the learning of Indonesian language. This research indicates that the application of SQ3R model can improve comprehension

comprehension if applied properly and in accordance with the implementation stage. Implementation of SQ3R model that is not perfect, less improve student learning result read comprehension. This is seen in classroom action research in cycle I to cycle III. Based on the research objectives, it can be concluded that the efforts of teachers to apply SQ3R model in reading comprehension learning can improve students' understanding of the reading. the details are as follows. 1) Increased reading progress through SQ3R model, every cycle I average score $56,44 \%$, cycle II average value $66,11 \%$, cycle III achievement result $88,11 \%$. 2) The atmosphere of teaching and learning process goes well. All students do the job actively. This is seen when students strive to implement the stages of the strategy. Students can mention things that are known to the topic topics, can recount in their own words as well as summarize the content of the reading. 3) Activity of students in learning to run well because of its motivation to learn.
\end{abstract}

Keywords: SQ3R learning model

\section{PENERAPAN MODEL PEMBELAJARAN SQ3R UNTUK MENINGKATKAN HASIL BELAJAR DAN AKTIFITAS SISWA DALAM BELAJAR BAHASA INDONESIA}

\author{
ABSTRAK
}


Untuk bisa mempelajari sesuatu pelajaran dengan baik, kita perlu mendengar, melihat, mengajukan pertanyaan tentangnya, dan membahasnya dengan orang lain. Bukan cuma itu, guru perlu "mengerjakannya", yakni menggambarkan sesuatu dengan cara mereka sendiri, menunjukkan contohnya, mencoba mempraktekkan keterampilan dan mengerjakan tugas yang menuntut pengetahuan yang telah mereka dapatkan.

Permasalahan yang ingin dikaji dalam penelitian ini adalah: Apakah menggunakan model SQ3R dapat meningkatkan hasil belajar siswa SD N 30 Timbulun pada pelajaran bahasa Indonesia ? Langkah - langkah yang dilakukan dalam menggunakan model pembelajaran SQ3R ?

Tempat pelaksanaan penelitian ini adalah SD Negeri 30 Timbulun. Mata Pelajaran dan Karakteristik siswa. Mata pelajaran yang diperbaiki adalah mata pelajaran bahasa Indonesia, adapun jumlah siswa yang menjadi sasaran penelitian di kelas I sebanyak 27 orang yang terdiri 15 orang perempuan dan 12 orang laki-laki.

Penelitian ini adalah berupa proses (observasi dan catatan lapangan) dan hasil berupa tes. Observasi digunakan untuk mendapatkan data tentang siswa dalam mengikuti pembelajaran bahasa Indonesia.

\section{Kata kunci : model pembelajaran SQ3R}

\section{PENDAHULUAN}

pendidikan nasional pada dasarnya merupakan bagian dari upaya pencapaian tujuan pembelajaran nasional dituangkan dalam kurikulum pendidikan nasional yang berbunyi :“ Pendidikan nasional berfungsi mengembangkan kemampuan dan mencerdaskan kehidupan bangsa bertujuan untuk berkembangnya potensi peserta didik agar menjadi manusia beriman dan bertakwa kepada Tuhan Yang Maha Esa, berakhlak mulia, sehat, berilmu, cakap, kreatif, dan mandiri, menjadi warga Negara yang demokratis serta bertanggungjawab. "UndangUndang Sisdiknas No. 20 tahun 2003 (dalam Arifin 2007 : 98)".

Dalam upaya untuk memajukan kehidupan suatu bangsa dan Negara sesuai
Penelitian ini menunjukkan bahwa penerapan model SQ3R dapat meningkatkan kemampuan membaca pemahaman jika diterapkan dengan baik dan sesuai dengan tahap pelaksanaannya. Penerapan model SQ3R yang tidak sempurna, kurang meningkatkan hasil belajar siswa membaca pemahaman. Hal ini terlihat dalam penelitian tindakan kelas pada siklus I sampai siklus III.

Berdasarkan dengan tujuan penelitian, secara khusus dapat disimpulkan bahwa upaya guru menerapkan model SQ3R dalam pembelajaran membaca pemahaman dapat meningkatkan pemahaman siswa terhadap bacaan. dengan rincian sebagai berikut. 1) Peningkatan kemajuan membaca melalui model SQ3R, setiap siklus I nilai rata- rata $56,44 \%$, siklus II nilai rata-rata $66,11 \%$, siklus III pencapaian hasil $88,11 \%$. 2) Suasana proses belajar mengajar berjalan dengan baik. Semua siswa mengerjakan tugas secara aktif. Hal tersebut terlihat ketika siswa berusaha keras melaksanakan tahapan-tahapan strategi tersebut. Siswa dapat menyebutkan hal-hal yang diketahui tenatang topik bacaan, dapat menceritakan kembali dengan kata-kata sendiri serta mempu menyimpulkan isi dari bacaan. 3) Keaktifan siswa dalam belajar mengajar berjalan dengan baik karena termotifasinya untuk belajar. dengan tujuan yang telah dirumuskan maka di dalamnya terjadi proses pendidikan atau proses belajar mengajar dan memberikan pengertian pada pandangan dan penyesuaian bagi sesorang ataui murid terdidik kearah kematangan dan kedewasaan. Proses ini akan membawa pengaruh terhadap perkembangan jiwa dan potensi peserta didik kearah yang lebih dinamis baik terhadap bakat atau pengalaman, moral, intelektual, maupun fisik, (jasmani).

Dewasa ini yang menjadi pembicaraan hangat dalam masalah mutu pendidikan adalah prestasi belajar murid dalam suatu bidang ilmu tertentu. Menyadari hal tersebut, maka pemerintah bersama para ahli pendidikan berusaha untuk lebih meningkatkan mutu 
pendidikan. Upaya pembahasan pendidikan telah banyak dilakukan oleh pemerintah, di antaranya melalui seminar, lokakarya, dan pelatihanpelatihan dalam hasil penetapan materi pelajaran serta metode pembelajaran untuk bidang studi tertentu misalnya IPA, Matematika, bahasa Indonesia, dan lain-lain.

Sudah banyak yang dilakukan Indonesia untuk meningkatkan kualitas pendidikan, khususnya pendidikan bahasa Indonesia di sekolah, namun belum menampakkan hasil yang memuaskan, baik oleh tujuan dan proses pembelajarannya maupun dari hasil prestasi belajar muridnya.

Salah satu keterampilan berbahasa yang semakin penting peranannya dalam memasuki abad ke-21 adalah membaca. Dengan majunya teknologi di bidang media cetak,ribuan bahkan ratusan ribu judul / topic dari berbagai bidang pengetahuan yang terbit setiap harinya. Hanya dengan memiliki keterampilan membaca yang efesien dan efektif barbagai informasi yang bermanfaat dapat dipahami dengan mudah.

Kurikulum Satuan Tingkat Pendidikan (KTSP) SMA mata pelajaran bahasa Indonesia bertujuan agar perserta didik memiliki kemampuan sebagai berikut : (1) Berkomunikasi secara efektif dan efesien sesuai dengan etika yang berlaku, baik secara lisan maupun tulisan ; (2) Menghargai dan bangga menggunakan bahasa Indonesia sebagai bahasa persatuan dan bahasa Negara ; (3) Memahami bahasa Indonesia dan menggunakannya secara tepat dan kreatif untuk berbagai tujuan ; (4) Menggunakan bahasa Indonesia untuk meningkatkan kemampuan intelektual serta kematangan emosional dan sosial; (5) Menikmati dan memanfaatkan karya sastra untuk memperluas wawasan, memperhalus budi pekerti, serta meningkatkan pengetahuan dan kemampuan berbahasa;

(6) Menghargai dan membanggakan sastra Indonesia sebagai khazanah budaya dan intelektual manusia Indonesia.

Tingkat kecepatan (efesiensi) dan ketepatan ( efektivitas) membaca teks bacaan siswa SD yang ideal menurut Nurhadi (1989 : 29) adalah 200 kata permenit. Efesiensi dan efektifitas yang ideal tersebut bisa saja dicapai secara bertahap, bila siswa SD sungguh berlatih dengan 4 jenis keterampilan membaca tersebut dibimbing oleh segenap guru secara maksimal.

Membaca merupakan suatu kegiatan yang bertujuan untuk memahami isi bacaan melalui kegiatan pengenalan kata demi kata atau kalimat demi kalimat. Membaca menurut Antony (dalam Miller, 1993 ; 283) bukan hanya sekedar melafalkan huruf demi huruf atau kata demi kata dalam wacana, melainkan suatu proses penyusunan makna melalui interaksi yang dinamis antara pengetahuan pembaca yang dikuasainya dengan informasi yang ada dalam bahasa tulis dan konteks situasi membaca.

$$
\text { Membekali kemampuan dan }
$$

keterampilan membaca murid SD diperlukan pembelajaran membaca permulaan. Pembelajaran membaca di kelas tinggi yaitu kelas I disebut membaca pemahaman atau membaca lanjut. Pemahaman isi dimulai dengan dapatnya murid. (a) mengajukan atau menjawab pertanyaan sesuai isi bacaan; (b) mengemukakan gagasan utama; (c) menceritakan kembali dengan kata-kata sendiri (meringkas bacaan); (d) mengemukakan gagasan / pesan cerita dan sifat pelaku; (e) menentukan bagian yang menarik dalam cerita. Dankin (1989:7) membaca merupakan kegiatan menelaah kata-kata pengarah dan memahami isinya sesuai konteks yang ada.

Berdasarkan uraian tersebut membaca dapat dikatakan sebagai suatu proses memahami gagasan dan ide penulis yang tertuang dalam bacaan lalu menghubungkannya dengan pengalaman / skemata pembaca sebelumnya secara kritis, kemudian interaksi ilmiah yang dinamis tersebut dikembangkan secara kreatif.

Berdasarkan survey yang dilakukan di SD Negeri 30 Timbulun khususnya kelas I diperoleh informasi bahwa kondisi pembelajaran membaca di kelas tersebut pada umumnya mengalami hambatan yang cukup serius. Hal tersebut belum adanya proses pembelajaran yang inovatif. Pembelajaran masih dilaksanakan dengan cara yang konvensional yaitu murid diberi tugas membaca di sekolah atau di rumah. Tugas itu murid menjawab pertanyaanpertanyaan seputar isi bacaan tersebut. Proses murid membaca bukanlah tujuan utama. Tujuannya adalah murid mengerjakan tugas sesuai keinginan guru.

Hasil observasi dan wawancara yang dilakukan selama tiga hari di sekolah itu bersama guru dan murid dapat ditarik kesimpulan bahwa (1) pembelajaran membaca masih menggunakan model yang kurang inovatif;

kekuranginovatifan tersebut menjadi kegiatan membaca murid hanya terbatas pada tugas yang dibebankan ; (3) kurangnya membaca murid 
menjadikan rendahnya tingkat pemahaman murid terhadap isi bacaan hanya apabila murid diberi kesempatan untuk membuka kembali bacaan; (4) rendahnya tingkat / mereka kurang mampu mengungkapkan kembali isi cerita baik secara lisan maupun tulisan dengan menggunakan bahasa murid sendiri.

Data yang ada pada murid dalam penilaian membaca pemahaman memperoleh nilai rata-rata kemampuan membaca pemahaman pada tahun 2015 hanya 57,17 masih berada dibawah nilai KKM di sekolah tersebut yaitu 65 dari nilai ideal 100. Kondisi pembelajaran membaca pemahaman pada sekolah tersebut perlu segera diperbaiki. Jalan keluar yang akan dilakukan untuk mengatasi permasalahan yang ada adalah pemberian alternatif pelaksanaan pembelajaran membaca dengan model, teknik, pendekatan yang berbeda.

Di samping itu, pendekatan yang diambil juga harus dapat menggambarkan tingkat pemahaman murid yang menyeluruh, baik pada pemahaman isi yang ditujukan dengan kemampuan murid mengungkapkan kembali isi bacaan baik secara lisan maupun tulisan.

Untuk mengatasi dampak negatif terhadap ketidakmampuan membaca dan memahami isi bacaan dengan baik, diperlukan suatu teknik atau model pembelajaran yang berorientasi pada aktivitas proses pemahaman.

Banyak model-model pembelajaran yang dapat diterapkan oleh guru dalam pengajaran membaca pembelajaran di SD seperti: model Survey, Question, Read, Recall, Review, (SQ3R), model DIA, model DRTA, model KWL, dan model GRP. Salah satu alternatif pemecahan masalah yang digunakan dalam meningkatkan aktivitas membaca pemahaman adalah dengan menggunakan model SQ3R. Model ini dirancang oleh Robinson pada tahun 1961 yang dapat digunakan dalam pembelajaran membaca untuk meningkatkan daya ingat pemahaman murid terhadap isi bacaan (dalam Burn, 1996:429)

SQ3R adalah singkatan dari Survey, Question, Read, Recall, Review. Tahap pelaksanaannya adalah (1) Survey (menyurvey), tahap mengetahui identitas buku (2) Question (bertanya dalam hati) tahap membuat pertanyaan-pertanyaan yang bersifat produktif, (3) Read (membaca) tahap membaca secara teliti, (4) Recall (mengendapkan dan mengingat kembali), tahap seseorang mengendapkan apa yang telah dipahami, (5) Review (melihat ulang secara selintas), tahap ini dilakukan dengan membaca keseluruhan isi buku secara sepintas. Di samping itu, tahap ini juga dapat dijadikan sarana untuk menemukan hubungan antar bagian dalam buku sehingga informasi yang diperoleh utuh. (Direktorat PLP, 2008).

Untuk mengetahui bahwa membaca bukan hanya sekedar menggunakan kata demi kata tetapi juga dapat memahami isi bacaan tersebut, seorang guru dapat menerapkan salah satu model pembelajaran membaca pemahaman. Untuk melihat hasil penerapan atau penggunaan model pembelajaran membaca pemahaman dalam pembelajaran bahasa Indonesia maka penulis ingin melakukan penelitian pada murid kelas I SD Negeri 30 Timbulun, dan yang akan digunakan atau diterapkan dalam pembelajaran membaca pemahaman adalah model SQ3R.

Berdasarkan uraian di atas, penulis ingin mengadakan penelitian tentang membaca pemahaman pada mata pembelajaran bahasa Indonesia menerapkan salah satu model pembelajaran sehingga menetapkan sebuah judul penelitian. Adapun judul penelitian yang akan dilakukan oleh penulis adalah sebagai berikut : "Meningkatkan keterampilan membaca pemahaman melalui penggunaan penbelajaran model survey, read, recall, review (SQ3R) pada siswa kelas I SD Negeri 30 Timbulun".

Rumusan Masalah sebagai berikut : 1) Bagaimana menerapkan model pembelajaran SQ3R untuk meningkatkan hasil belajar dan aktifitas murid dalam mata pelajaran bahasa indonesia murid kelas I SD Negeri 30 Timbulun pada pelajaran Bahasa Indonesia ?

Pemecahan Masalah, berdasarkan rumusan masalah di atas, peneliti merencanakan penyelesaian masalah melalui tindakan perbaikan keterampilan membaca pemahaman pada pelajaran bahasa Indonesia melalui pembelajaran model SQ3R. Alasan penggunaan pembelajaran model SQ3R agar murid lebih mudah memahami apa yang dibaca, sehingga mampu mendapatkan hasil belajar yang lebih baik.

Siklus pertama guru membimbing murid agar dapat meningkatkan aktivitas membaca pemahaman dengan mendorong murid untuk memahami suatu bacaan. Pada siklus ini diharapkan dapat menunjukkan perkembangan dan hambatan yang dialami murid selama melakukan proses pembelajaran dengan menggunakan model SQ3R. Persiapan proses dan hasil belajar dapat ditunjukkan dengan penggunaan pembelajaran model SQ3R. 


\begin{tabular}{llllllr}
\hline Pencapaian proses dan hasil & \multicolumn{2}{c}{ Tujuan } & dari & penerapan & model \\
pembelajaran tentang membaca pemahaman & pembelajaran & SQ3R & dalam & membaca \\
siswa dilakukan dalam bentuk daur ulang yang & pemahaman adalah & untuk peningkatan \\
terdiri atas tiga siklus. Apabila ada peningkatan & keterampilan membaca pemahaman melalui & mas a \\
pada siklus pertama akan dilanjutkan ke siklus & model pembelajaran SQ3R pada siswa kelas I \\
kedua, dan apabila siklus kedua tidak ada & SD Negeri 30 & Timbulun pada pelajaran bahasa \\
peningkatan maka dapat diulang pada siklus & Indonesia. & & &
\end{tabular}
ketiga.

\section{PROSEDUR DAN PELAKSANAAN PENELITIAN}

Tempat pelaksanaan penelitian ini adalah SD Negeri 30 Timbulun. Mata pelajaran yang diperbaiki adalah mata pelajaran bahasa Indonesia, adapun jumlah siswa yang menjadi sasaran penelitian di kelas I sebanyak 27 orang yang terdiri 15 orang perempuan dan 12 orang laki-laki.

Penelitian ini adalah berupa proses (observasi dan catatan lapangan) dan hasil berupa tes. Observasi digunakan untuk mendapatkan data tentang siswa dalam mengikuti pembelajaran bahasa Indonesia.

Secara garis besar prosedur atau pengembangan tindakan penelitian dapat dilakukan melalui empat tahap yaitu tahap perencanaan, tahap tindakan, tahap observasi dan tahap refleksi. Namun penelitian tindakan kelas menggunakan tahap orientasi pada awal kegiatan, sedangkan pelaksanaan tindakan tiga siklus dimana setiap siklus dilakukan tiga kali pembelajaran. a. Mengadakan konsultasi dengan kepala sekolah dalam pelaksanaan penelitian; b. Melakukan diskusi dengan guru kelas I untuk mendapatkan gambaran bagaimana penggunaan model pelajaran membaca dalam pengajaran bahasa Indonesia; c. Mengadakan observasi awal terhadap pelaksanaan model pelajaran membaca di kelas, sekaligus memahami karakteristik pembelajaran. Tujuannya untuk mengetahui gambaran pelaksanaan bahasa Indonesia di kelas sebagai langkah awal membuat rancangan model pembelajaran yang akan digunakan dalam pelaksaan tindakan.

Rencana pelaksanaan tindakan dilakukan sebanyak tiga siklus yakni sebagai berikut : Menyamakan persepsi antara penelitian guru tentang model pembelajaran membaca pemahaman yang akan dilakukan dalam pengajaran bahasa Indonesia dengan kompetensi dasar "menemukan pikiran pokok teks agak panjang (150 - 200 kata) dengan membaca sekilas bacaan dengan tema "Peristiwa"; Menyusun rancangan tindakan pembelajaran dengan menggunakan model SQ3R untuk membaca pemahaman; Menentukan strategi pelaksanaan model SQ3R yang efektif sehingga dapat meningkatkan kemampuan membaca intensif siswa dalam mata pelajaran bahasa Indonesia; Melakukan diskusi balikan, untuk mencari kelemahan yang dilakukan selama pembelajaran yang menggunakan model SQ3R membaca pemahaman.

Tahap ini merupakan implementasi pelaksanaan rancangan yang telah disusun secara kolaboratif antara peneliti dan guru, di mana peneliti sebagai observer dan guru sebagai pelaksana. Kegiatan yang akan dilakukan pada setiap siklus adalah sebagai berikut : 1 . Rancangan siklus Pertama 2. Rancangan pembelajaran siklus ke Dua 3. Rancangan siklus Ke 3 a. Menyusun rencana untuk membaca pemahaman yang akan digunakan dalam pembelajaran bersama dengan guru untuk tindakan ketiga yang berdasarkan hasil refleksi dari tindakan kedua; b. Menyusun model SQ3R dalam membaca pemahaman berdasarkan refleksi pada siklus kedua dan sesuai dengan substansi materi pembelajaran siklus ketiga; c. Merencanakan pengajaran yang menggunakan model SQ3R sebagai cara untuk meningkatkan kemampuan membaca pemahaman; $d$. Melaksanakan pengajaran dengan menggunakan model SQ3R untuk membaca pemahaman pada mata pelajaran bahasa Indonesia; e. Melakukan observasi menggunakan model SQ3R dalam pembelajaran yang fokus pengamatannya disesuaikan dengan refleksi pada siklus kedua; $f$. Melakukan diskusi balikan untuk menetapkan keabsahan data yang didapat selama pelaksanaan penelitian.

Teknik pengumpulan data penelitian ini menggunakan teknik instrumen utama dan 
instrumen penunjang. Instrumen utama adalah peneliti sendiri yang memiliki syarat, kemampuan mengumpulkan, menyeleksi, menilai, menyimpulkan dan menentukan data.

Data dikumpulkan dengan beberapa cara yaitu : Observasi, Tes Tes digunakan untuk mengetahui kondisi awal secara riil pada kelas yang menjadi subjek penelitian. Teknik wawancara yang digunakan untuk mengumpulkan data tentang kondisi awal yang riil pada subjek penelitian. Suatu bentuk uji mereproduksi kembali suatu yang telah dibaca. Uji ini dapat menjadi gambaran kemajuan siswa dalam memahami suatu bahan bacaan.

Teknik yang digunakan dalam analisis data yang dilaksanakan adalah analisis catatan lapangan yang diperoleh dari observasi oleh kolabolator, peneliti, dan balikan dari murid diperoleh dari selama observasi dan wawancara untuk mengetahui informasi tersebut.

Analisis data yang digunakan dalam penelitian ini adalah dimulai dari analisis terhadap aktivitas membaca murid dalam proses pembelajaran dan hasil belajar aktivitas membaca dengan menggunakan model SQ3R.

Analisis data adalah merangkum secara akurat data dengan benar. Data yang dianalisis adalah aspek murid yang terdiri atas aktivitas pada saat proses pembelajaran berlangsung dan hasil tugas yang diberikan oleh guru. Data pada saat proses pembelajaran ditafsirkan dapat menggunakan rumus sebagai berikut :

\section{jumlah yang muncul \\ jumlah yang seharusnya \\ x $100 \%$}

\section{Tabel Tingkat Keberhasilan}

\begin{tabular}{|l|l|}
\hline Taraf Keberhasilan & Kualifikasi \\
\hline $85 \%-100 \%$ & Sangat Baik (SB) \\
$70 \%-84 \%$ & Baik (B) \\
$55 \%-69 \%$ & Cukup (C) \\
$46 \%-54 \%$ & Kurang (K) \\
$0 \%-45 \%$ & Sangat Kurang (SK) \\
\hline
\end{tabular}

Penelitian ini yang menjadi instrumen peneliti adalah format observasi dan lembar kerja siswa (butir soal tes tertulis). Untuk menjalankan fungsi sebagai instrumen peneliti mengamati setiap aktivitas guru dalam melaksanakan pembelajaran di dalam kelas dengan menggunakan format observasi kegiatan pembelajaran untuk guru.

Lembar kerja siswa yang berisikan butirbuitr soal yang diberikan pada murid diakhiri pelaksanaan kegiatan pembelajaran tes ini diberikan kepada seluruh murid kelas I SD Negeri 30 Timbulun Menjadi salah satu subjek penelitian hasil tes akan dijadikan sebagai bahan untuk merefleksikan tingkat pemahaman murid terhadap materi pembelajaran. Di samping itu juga untuk mengetahui sejauh mana keberhasilan guru dalam melaksanakan proses pembelajaran.

Indikator Keberhasilan Indikator Proses Tindakan dikategorikan berhasil bila minimal $80 \%$ pelaksanaannya telah sesuai dengan pembelajaran bahasa Indonesia melalui penggunaan model SQ3R dalam membaca pemahaman; Indikator Hasil Tindakan dikatakan berhasil bila minimal $75 \%$ siswa telah memperoleh nilai 70 . 


\section{HASIL DAN PEMBAHASAN}

Deskripsi Hasil hasil penelitian proses pembelajaran membaca pemahaman melalui penerapan model SQ3R (Survey,Question,Read,Recall,Review) yang dimulai dengan pratindakan. Hal ini dilakukan untuk mengetahui hambatan-hambatan kemampuan siswa membaca pemahaman sebelum diterapkan model SQ3R. Pelaksanaan tindakan dilaksanakan setiap siklus. Setiap siklus dilaksanakan satu kali pertemuan.

Data setiap siklus dipaparkan secara berurut dan terpisah agar peneliti dapat melihat adanya persamaan, perbedaan, dan perkembangan yang terjadi pada setiap siklus. Kegiatan awal, peneliti berkunjung ke SD Negeri 30 Timbulun untuk menjejaki masalah yang berkaitan dengan hasil belajar siswa membaca pemahaman.

Hasil wawancara guru kelas I pemahaman siswa terhadap pemahaman masih rendah, nilai rata-rata yang diperoleh siswa hanya 50,33. Hal ini dinilai berada pada kategori sangat kurang. Sehingga ditetapkan pelakasanaan proses pembelajaran membaca pemahaman dengan mengikuti jadwal yang ada dikelas I.

Siklus I, penerapan model SQ3R belum diterapkan secara sempurna. Tahap menyurvey, guru kurang memotivasi siswa membaca kalimat-kalimat yang penting serta tidak tepat waktu. Begitu pula tahap question guru kurang membimbing siswa untuk membuat dan mengajukan pertanyaan yang berhubungan dengan topik bacaan. Hal ini menyebabkan rendahnya perolehan nilai siswa membaca pemahaman.

Data tersebut dapat dijelaskan bahwa hasil belajar siswa membaca pemahaman siklus I mencapai skor rata-rata kelas pencapaian ketuntasan belajar 56,44\%. Prestasi tersebut berada pada kualifikasi kurang baik (KB). Masih ada 14 siswa berkemampuan di bawah kategori baik.

Meskipun demikian, hasil yang dicapai siswa mengalami sedikit kemajuan bila dibanding sebelum diadakan penerapan model SQ3R. hal ini dilihat nilai rata-rata kelas 50,33 dengan menjadi 56,44 . Hasil yang dicapai siswa masih rendah maka pembelajaran pada siklus II masih perlu dilanjutkan.

Siklus II, penerapan SQ3R masih kurang sempurna. Karena waktu yang digunakan guru tidak efisien. Tahap question siswa belum mampu mengajukan pertanyaan. Hal ini disebabkan guru kurang memberikan bimbingan kepada siswa. Begitu pula pada kegiatan read, recall, dan review siswa masih kurang mampu menjawab pertanyaan karena guru kurang memberi bimbingan kepada siswa.

Data tersebut dapat dijelaskan bahwa hasil belajar siswa membaca pemahaman menunjukkan adanya peningkatan. Hal ini ditandai dengan pencapaian skor rata-rata kelas $66,11 \%$ dengan ketuntasan belajar 6,61\%. Hasil tersebut berada pada kualifikasi baik (B). Meskipun belum mencapai tarap keberhasilan yang ditargetkan, namun hasil yang dicapai pada siklus II mengalami sedikit peningkatan dibanding pada siklus I. Hal ini dapat dinilai dari nilai rata-rata kelas pada siklus I dari 56,44 menjadi 66,11 dan ketuntasan belajar 6,11\%.

Kelemahan yang terdapat siklus I dan siklus II. Guru menyempurnakan setiap tahapan strategi model SQ3R. Sehingga hasil belajar siswa membaca pemahaman lebih meningkat. Penyempurnaan model SQ3R tersebut anatara lain :

1) Tahap survey

a. Memancing skemata siswa yang berhubungan dengan topik bacaan;

b. Memberi motivasi siswa membaca dalam hati.

2) Tahap question (bertanya dalam hati)
a. Membimbing siswa mengajukan pertanyaan berdasarkan judul / topik yang terdapat dalam bacaan;
b. Membimbing siswa membuat pertanyaan.

3) Tahap read (membaca)

a. Membimbing siswa mencari informasi penting dari setiap paragraf;

b. Memberi motifasi siswa menjawab pertanyaan;

c. Memberi contoh terhadap siswa cara menjawab pertanyaan dengan baik;

d. Mengarahkan siswa untuk tidak membuat atau tanda-tanda.

4) Tahap recall (mengendapkan dan mengingat kembali)

a. Pengarahkan siswa untuk mengingat kembali apa yang telah dibaca;

b. Pembimbing siswa menjelaskan dengan kata-kata sendiri terhadap apa yang telah dibaca;

c. Mengarahkan siswa menbuat catatan seperlunya. 
5) Tahap review (melihat ulang secara selintas)

a. Mengarahkan siswa untuk membaca ulang secara keseluruhan terhadap teksbacaan yang telah dibaca;

b. Mengarahkan siswa untuk menemukan pokok-pokok penting yang perlu untuk diingat;

c. Mengarahkan siswa untuk menyimpulkan materi yang telah dibaca.

Hasil belajar siswa membaca pemahaman pada siklus III mencapai rata-rata kelas 81,12 dengan ketuntasan belajar 100\%. Hasil belajar siswa tahap ini berada pada kualifikasi sangat baik (SB). Adapun perbandingan hasil belajar siswa membaca pemahaman yang dimulai siklus I, II, dan III adalah sebagai berikut : 1 . Pratindakan pencapaian hasil $0 \% 2$. Pelaksanaan siklus I pencapaian hasil 56,44\% 3. Pelaksanaan siklus II pencapaian hasil $66,11 \%$ Pelaksanaan siklus III pencapaian hasil $88,11 \%$.

tenatang topik bacaan, dapat menceritakan kembali dengan kata-kata sendiri serta mempu menyimpulkan isi dari bacaan. Keaktifan siswa dalam belajar mengajar berjalan dengan baik karena termotifasinya untuk belajar.

Saran penelitian Penerapan model SQ3R sanagat baik diterapkan untuk meningkatkan hasil belajar siswa membaca pemahaman di Sekolah Dasar, Penerapan model SQ3R disarankan hal-hal sebagai berikut : 1. Guru hendaknya mengawali pembelajaran dengan memancing skemata siswa melalui Tanya jawab; 2. Mengawasi siswa untuk mengajukan dan membuat pertanyaan sesuai dengan judul/topik bacaan; 3. Guru hendaknya melatih siswa membaca dan mengarahkan siswa mencari informasi penting dari setiap paragraph sambil mencari jawaban atas pertanyaan yang telah diajukan sebelumnya. 4. Guru melatih siswa mengingat kembali apa yang telah dibaca dan membimbing siswa mengungkapkan isi bacaan dengan kata-kata sendiri; 5. Guru melatih membuat kesimpulan dengan kata-kata sendiri. 


\section{DAFTAR PUSTAKA}

Antony, Miller 1993, Meningkatkan Kemampuan Membaca.

Arifin, Anwar, 2007. Profil Guru dan Dosen Indonesia. Jakarta : Pustaka Indonesia Kerja Sama Pokja Diknas.

Bloon dkk. ( Dimayani 2006 ). Kemampuan Berbahasa Indonesia di Sekolah Dasar. Bandung: UPI PRESS.

Burns. 1996. Bagaimana Memotivasi Anak Balajar. Jakarta : Grasindo.
Cohrain. 1984. Membaca dan Menulis di SD Teori dan Pengajarannya. Bandung : UPI PRESS.

Dankin. 1989. Model-model Pembelajaran. Jakarta : Dit. Pendidikan LanjutanPertama.

Direktorat PLP, 2008. Kamus Besar Bahasa Indonesia. Jakarta : Balai Pustaka. 